\title{
PENDAMPINGAN PEMASARAN ONLINE TANAMAN HIAS DENGAN PERBAIKAN PROMOSI MELALUI TEKNIK FOTOGRAFI SEDERHANA
}

\author{
Suswadi*1, Agung Prasetyo ${ }^{2}$, Wiyono ${ }^{3}$, Teguh Supriyadi ${ }^{4}$, Eko Hartoyo ${ }^{5}$ \\ 1,2,3,4,5 Universitas Tunas Pembangunan Surakarta \\ *e-mail: suswadi.suswadi@lecture.utp.ac.id
}

\begin{abstract}
ABSTRAK
Peningkatan kesejahteraan masyarakat dari waktu ke waktu mengakibatkan peningkatan permintaan akan barang tersier. Barang tersier akan diantaranya adalah barang untuk keperluan kemewahan dan pariwisata termasuk didalamnya barang untuk pemenuhan kesenangan atau hobi. Salah satu hobi yang sedang mendapatkan respon baik dipasar saat ini adalah hobi akan tanaman hias. Kegiatan pengabdian yang akan dilaksanakan milibatkan ibu-ibu rumah tangga Desa Tawangmangu sebagai mitra. Pemberdayaan melalui program pengabdian ini akan dilakukan melalui kegiatan produktif untuk memaksimalkan potensi desa melalui peningkatan sumber daya manusia. Hasil dari pelatihan ini adalah perbaikan promosi dengan teknologi sederhana yang telah dilaksanakan mampu meningkatkan pengetahuan dan kemampuan peserta dalam memanfaatkan kamera HP untuk menghasilkan gambar yang menarik dalam promosi penjualan produk tanaman hias. Mitra juga semakin luwes dalam memanfaatan sosial media sebagai alat jual beli online.
\end{abstract}

Kata kunci: Pelatihan,Sosial media, Fotografi, komposisi

\begin{abstract}
Increasing the welfare of society from time to time results in an increase in demand for tertiary goods. Tertiary goods include goods for luxury and tourism purposes, including goods for the fulfillment of pleasure or hobbies. One of the hobbies that are getting a good response in the market today is the hobby of ornamental plants. The service activities that will be carried out will involve the housewives of Tawangmangu Village as partners. Empowerment through this community service program will be carried out through productive activities to maximize the potential of the village through increasing human resources. The results of this training are promotion improvements with simple techniques that have been implemented that have been able to increase the knowledge and abilities of participants in utilizing cellphone cameras to produce attractive images in sales promotion of ornamental plant products. Partners are also more flexible in using social media as a means of buying and selling online.
\end{abstract}

Keywords: training, social media, photography, composition

\section{PENDAHULUAN}

Peningkatan kesejahteraan masyarakat dari waktu ke waktu mengakibatkan peningkatan permintaan akan barang tersier. Barang tersier akan diantaranya adalah barang untuk keperluan kemewahan dan pariwisata termasuk didalamnya barang untuk pemenuhan kesenangan atau hobi. Salah satu hobi yang sedang mendapatkan respon baik dipasar saat ini adalah hobi akan tanaman hias. Di Indonesia, banyak terdapat areal pertanian yang potensial untuk pengembangan tanaman hias salah satunya krisan, melati mawar, anturium, anggrek dan lain-lain.

Tanaman hias termasuk kedalam subsektor hortikultura dalam pengklasifikasian di Jawa Tengah. Subsektor hortikultura memiliki peranan yang cukup penting dan strategis dalam pembangunan nasional karena mampu memberikan kontribusi yang nyata, baik dalam penyediaan produk pangan, kesehatan, kosmetika, perdagangan, penyerapan tenaga kerja dan 
meningkatkan pendapatan petani. Upaya-upaya diversifikasi pangan dan peningkatan gizi masyarakat berhubungan erat dengan upaya peningkatan produksi tanaman hortikultura yang pada akhirnya akan meningkatkan sumber pendapatan bagi penduduk. Hasil Survei Pertanian Antar Sensus 2018 menunjukkan bahwa sebanyak 14,67 persen dari 4.469.728 rumah tangga usaha pertanian menjadikan budidaya tanaman hortikultura sebagai jenis usaha utama di Provinsi Jawa Tengah (Badan Pusat Statistik, 2020b).

Tanaman hias adalah tanaman yang mempunyai nilai keindahan dan estetika baik karena bentuk tanaman, warna dan bentuk daun, tajuk maupun bentuk pohon/batang, warna dan keharuman bunganya, sering digunakan sebagai penghias pekarangan, taman atau ruangan di rumah-rumah, gedung perkantoran, hotel, restoran maupun untuk kelengkapan upacara adat dan keagamaan (Badan Pusat Statistik, 2020b). Produksi tanaman hias yang mendominasi Provinsi Jawa Tengah tahun 2019 adalah krisan, sedap malam, melati dan mawar. Dibandingkan tahun 2018 komoditas unggulan yang mengalami kenaikan produksi adalah komoditas krisan dan sedap malam, sedangkan komoditas mawar dan melati mengalami penurunan produksi.

Pesatnya bisnis tanaman hias jenis anthurium di Indonesia khususnya di Jawa Tengah, kini menjadi fenomena baru. Maraknya anthurium yang menghiasi rumahrumah, sekolah melambangkan tanaman berdaun indah yang masih sejenis dengan sejumlah tanaman hias populer semacam aglaonema, philodendron, keladi hias, dan alokasia ini sedang banyak diburu. Dalam setahun terakhir ini, tanaman hias, terutama Anthurium naik daun kembali akibat adanya pengaruh covid-19 yang mengahruskan orang untuk tetap berada dirumah. Tanaman hias merupakan salah satu pengusir kebosanan dan mengisi kegiatan saat bekerja dari rumah dalam situasi pandemi. Potensi usaha baru tercipta kembali, orang beramai-ramai menjadi pecinta, kolektor, pemain (pedagang), dan pembudi daya. Kabupaten Karanganyar merupakan kabupaten pusat tanaman hias utamanya dari jenis anthurium baik anthurium bunga maupun athurium daun. Produksi anthurium daun Kabupaten karanganyar bahkan mencapai $80 \%$ produksi anthurium jawa tengah (Badan Pusat Statistik, 2020b).

Desa Tawangmangu yang merupakan salah satu desa di Kecamatan Tawangmangu yang pada umumnya penduduknya berprofesi sebagai petani, pedagang, buruh (tani, industri ataupun perhotelan. Mayoritas penduduk Desa Tawangmangu yang umumnya berkerja sebagai petani dan buruh memiliki tingkat pendapatan rata-rata tergolong rendah, apalagi istri dari petani atau buruh tersebut tidak mempunyai pekerjaan tetap selain mengurus rumah tangga. Pertanian tanaman bahan makanan merupakan salah satu sektor dimana produk yang dihasilkan menjadi kebutuhan pokok hidup rakyat. Di Kecamatan Tawangmangu sangat potensial untuk tanaman hortikultura (Badan Pusat Statistik, 2020a). Masalah tersebut menjadi semakin rumit melihat situasi sekarang dengan merebaknya pandemi Covid-19 yang mana berdampak pada kegiatan ekonomi masyarakat baik di kota maupun dipedesaan. Pandemi Covid 19 memaksa seluruh sektor untuk melakukan transaksi perdagangan secara online, tidak terkecuali bisnis dibidang pertanian. Jika sebelum pandemi petani bebas untuk berdagang, setelah pandemi seperti sekarang guna menekan penyebaran pandemi model usaha dan perdagangan semacam itu tidak dapat dilakukan.

Kegiatan pengabdian yang akan dilaksanakan milibatkan ibu-ibu rumah tangga Kelompok PKK Desa Tawangmangu, Kecamatan Tawangmangu sebagai mitra. Pemberdayaan melalui program pengabdian ini akan dilakukan melalui kegiatan produktif untuk memaksimalkan potensi desa melalui peningkatan sumber daya manusia. Salah satu sumber daya alam yang sangat potensial adalah komoditas tanaman hortikultura utamanya tanaman hias. Tanaman hias bahkan sudah dibeli pembeli secara langsung dari berbagai daerah disekitar maupun diluar Kabupaten karanganyar. 
Situasi pandemi virus corona atau covid-19 dewasa ini memaksa seluruh kegiatan perdagangan tidak mungkin untuk dilakukan seperti pada kondisi normal. Pengumpulan masa dalam jumlah banyak seperti dipasar akan dikurangi dan dilarang guna mencegah penyebaran virus. Kondisi ini tentu memaksa petani dan kegiatan usaha dilakukan secara online. Bisnis tanaman hiaspun juga akan beradaptasi dengan bisnis online dimana pemasaran akan sangat bergantung dengan jaringan internet. Kegiatan yang akan dilakukan oleh ibu-ibu akan memberi dampak positif, selain memperindah halaman rumah tetapi juga meningkatkan pendapatan yang akan diterima keluarga. Dampak aspek ekonomi dan sosial adalah ibu-ibu rumah tangga menjadi memiliki pekerjaan, yang secara langsung akan meningkatkan pendapatan rumah tangga ataupun minimal bertahan ditengah situasi covid-19 seperti sekarang.

\section{METODE}

Metode yang digunakan adalah sosialisasi dan pelatihan terhadap peserta / mitra sejumlah 10 orang dengan menjaga dan menerapkan protokol kesehatan dalam suasana covid19. Kegiatan Pengabdian kepada Masyarakat ini dilaksanakan di RT 03 RW09 Kelurahan Tawangmangu Kecamatan Tawangmangu Kabupaten Karanganyar Provinsi Jawa Tengah. Kegiatan ini dilaksanakan dari tanggal 6 sampai 9 April 2021. Metode kegiatan dalam upaya pencegahan Peningkatan promosi dilakukan melalui: Edukasi Pemasaran Online di Era Covid-19, Edukasi kepada mitra dimaksudkan untuk memberikan informasi secara langsung terkait bahaya Covid- 19, mekanisme penularan dan penanganan serta dampak ekonomi dari covid-19 terutama pada pemasaranan komoditas pertanian. Memberikan semangat dan motivasi untuk terus bekerja, dan berkarya dalam mengembangkan UMKM ditengah pandemi. Pelatihan fotografi dilakukan dengan menenkankan pada efek pencahayaan dan pemanfaatan perlatan sederhana dalam mempercantik hasil gambar yang dilakukan menggunakan HP. Memberitahukan berbagai macam penggunaan fitur-fitur pada kamera HP yang membantu pengambilan gambar agar lebih menarik dan baik untuk dilihat. Pelatihan Promosi melalui sosial media dilakukan dengan memberikan pelatihan promosi dan posting agribisnis tanaman hias melalui status whatsapp, marketplace facebook.

\section{HASIL DAN PEMBAHASAN}

Sosialisasi dilakukan untuk mengedukasi peserta tentang peran sistem pemasaran secara online. Merespon terhadap adanya pandemi covid-19 pelatihan ditujukan untuk strategi pemasaran dengan penjualan langsung guna memastikan usaha berjalan dengan baik. Strategi ini akan lebih efektif jika dikembangkan bersamaan dengan pemasaran online lewat sosial media. Eksistensi UMKM memang tidak dapat diragukan lagi karena terbukti mampu bertahan dan menjadi roda penggerak ekonomi, terutama saat pandemi. Disisi lain, UMKM juga menghadapi banyak sekali permasalahan, yaitu terbatasnya modal kerja, SDM yang rendah, dan minimnya penguasaan ilmu pengetahuan serta teknologi (Harto, Pratiwi, Utomo, \& Rahmawati, 2019).

Sosialisasi dilakukan untuk mengedukasi mitra terkait sistem pemasaran yang lebih mudah dan modern. Selain itu, untuk mengetahui seberapa besar pengetahuan mitra tentang penerapan teknologi dalam pemasaran. Sosialisasi meliputi mengakses search engine marketing website dan sosial media, bagaimana berkomunikasi dan mencari informasi dengan media internet. Berdasarkan hasil observasi, pengetahuan dalam penerapan sosial media lebih tinggi dari pada pengetahuan tentang website, terutama pada media sosial whatsapp. Adapun 
kesulitan mitra dalam facebook, didominasi oleh tidak mengerti tentang market place dan ketentuannya. Instagram bahkan mitra tidak mengerti sama sekali dan hanya dua orang yang mempunyai, itupun kurang mengerti tentang highlight, story dan caption. Sementara pada informasi internet marketing website,mitra hanya tahu dari sebatas iklan di TV mengenai shopee, toko pedia dan platform penjualan online yang lain. Kecanggihan informasi internet sangat membantu pebisnis dalam mengembangkan usahanya (Kosasi, 2014)

Sosialisasi juga dilakukan dengan memberitahukan pentingnya pengambilan gambar dalam membantu promosi pemasaran secara online. fotografi adalah media berekspresi dan komunikasi yang kuat, menawarkan berbagai persepsi, interpretasi dan eksekusi yang tak terbatas. Secara garis besar arti fotografi adalah suatu proses atau metode untuk menghasilkan gambar atau foto dari suatu obyek dengan merekam pantulan cahaya yang mengenai obyek tersebut pada media yang peka cahaya (Erlyana \& Hidajat, 2019). Fotografi dapat dihasilkan dengan lebih efektif dan bermakna dengan penerapan dan pemahaman komposisi yang baik. Komposisi adalah sebuah alat yang digunakan oleh fotografer untuk mengarahkan para audience untuk merasakan melihat benda sekitar dengan lebih baik dari persepsi orang lain (Erlyana, 2021).

Pelatihan dilaksanakan dengan menggunakan metode experiential learning, yaitu melibatkan peserta secara aktif di setiap sesi pelatihan sehingga peserta belajar dan mengalami secara langsung setiap proses selama pelatihan. Kegiatan ini dilakukan dengan metode ceramah, tanya jawab, demonstrasi dan praktek langsung. Pertama mitra dilatih untuk mengambil gambar menggunakan konsep pencahayaan dari belakang atau dari samping objek dan berusaha mengambil gambar sedekat mungkin untuk mendapatkan fokus gambar. Pemanfaatan background dan semprotan air diberikan untuk memunculkan fokus dan komposisi yang lebih baik juga agar memunculkan warna bunga tanaman hias agar lebih menarik. Berikut adalah contoh gambar yang diambil dari peserta pada saat pelatihan dengan objek tanaman hias kuping leo (Pepperomia):

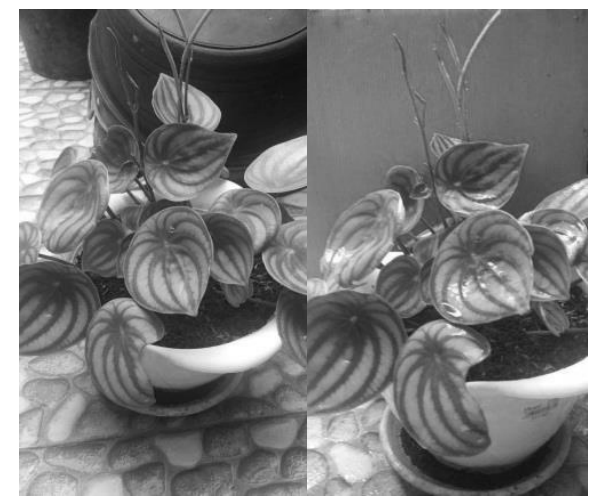

Gambar 1. Pelatihan Teknik Fotografi Sederhana

Pencahayaan paling dasar dapat dicapai adalah natural light, jenis pencahayaan alam, yang mana cahaya tersebut dihasilkan dari seluruh unsur alam. Unsur utama dalam pencahayaan alami bersumber pada cahaya matahari(Kusno \& Andri, 2011). Adapun pencahayaan matahari memiliki jam-jam tertentu yang baik untuk digunakan sebagai sumber cahaya dalam pemotretan. Untuk pagi hari antara 08.00 - 10.00 dan untuk sore hari 15.00 matahari terbenam. Hal ini dikarenakan pada jam-jam tersebut kekuatan sinar matahari tidak terlalu kuat, dan sudut pencahayaannya pun merata. Kemudian pelatihan dilakukan dengan mengedit foto dan mengunggahnya di sosial media membuat konten bisnis di sosial media melalui marketplace facebook dan caption pada instagram. Contoh tampilan konten produk dapat dilihat berikut ini: 
GANESHA: Jurnal Pengabdian Kepada Masyarakat

Vol. 1, (2) Juli 2021

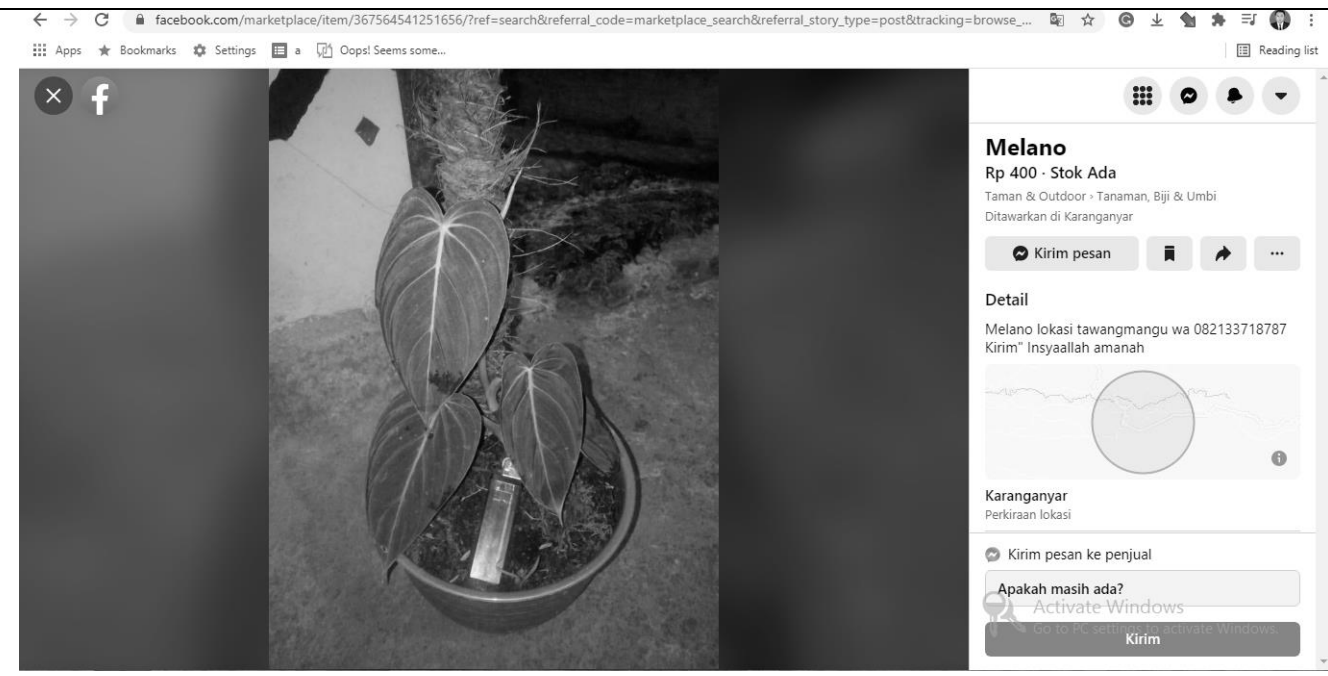

Gambar 2. Berjualan di Facebook Marketplace

Pelatihan cara berkomunikasi dengan pelanggan melalui whatsapp diberikan dengan cara mempromosikan produk ke konsumen agar lebih menarik dan cara merespon pesan dari konsumen yang baik dan benar. Berikut trik yang disampaikan yang dapat membantu mitra dalam berkomunikasi saat berjualan di whatsapp, pertama, Lengkapi identitas Whatsapp akun anda agar mudah diingat dan ditemukan oleh pelanggan (Foto dan Nama). Cantumkan nomor whatsapp anda pada toko online atau media sosial yang anda gunakan untuk mempromosikan produk anda(Tinaprilla \& Pratiwi, 2017). Sering-seringlah mengupdate status dengan konten yang unik mengenai produk-produk anda. Sajikan konten seunik mungkin agar menarik perhatian pelanggan. Berikan komentar terbaik untuk setiap pertanyaan dan tanggapan dari pelanggan anda.

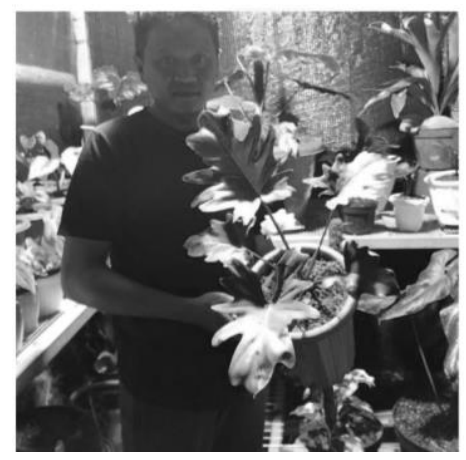

Gambar 3. Gambar dalam Akun Whatsapp Mitra

Berdasarkan observasi langsung keberhasilan pelatihan ini dipengaruhi oleh banyak hal, antara lain kompetensi trainer dalam memberikan materi, kelengkapan sarana dan peralatan untuk melakukan praktek. Evaluasi pelatihan yang terdiri dari evaluasi terhadap materi pelatihan, trainer atau pelatih. Menurut peserta pelatihan, materi yang diberikan sesuai dengan kebutuhan untuk bertahan dan mengembangkan usaha agribinis tanaman hias.

\section{KESIMPULAN}

Pelatihan perbaikan promosi dengan teknologi sederhana yang telah dilaksanakan mampu meningkatkan pengetahuan dan kemampuan peserta dalam memanfaatkan kamera HP untuk menghasilkan gambar yang menarik dalam promosi penjualan produk tanaman hias. Mitra juga semakin luwes dalam memanfaatan sosial media sebagai alat jual beli online. 
GANESHA: Jurnal Pengabdian Kepada Masyarakat Vol. 1, (2) Juli 2021

Dengan menggunakan media sosial sebagai alat pemasarannya diharapkan tetap mampu meraih pasar bahkan memperluas jaringan pasar agribisnis tanaman hias.

\section{UCAPAN TERIMA KASIH}

Terimakasih kepada warga Desa Tawangmangu, Kecamatan Tawangmangu, Kabupaten Karanganyar yang telah mengikuti kegiatan pengabdian masyarakat. Terima kasih kepada DRPMP UTP atas bantuan dana pelakasanaan pengabdian ini dan Terima kasih kepada segenap pihak-pihak yang telah membantu dalam proses kegiatan pengabdian pada masyarakat ini.

\section{DAFTAR PUSTAKA}

Badan Pusat Statistik. (2020a). Kecamatan Tawangmangu dalam Angka 2019. Karanganyar: Badan Pusat Statistik.

Badan Pusat Statistik. (2020b). Statistik Tanaman Hortikultura 2017-2019 Jawa tengah. Semarang: Badan Pusat Statistik Jawa Tengah.

Erlyana, Y. (2021). Pelatihan Fotografi Dan Videografi Secara Virtual Dalam Peningkatan Kemampuan Diri Pada Pandemic Covid-19. Jurnal Pengabdian Dan Kewirausahaan, 5(1), 47-54. Retrieved from https://journal.ubm.ac.id/index.php/pengabdian-dankewirausahaan/article/view/2725

Erlyana, Y., \& Hidajat, H. (2019). Pelatihan Pembuatan Kartu dengan Origami Mengambil Tema Hewan Langka Indonesia (RPTRA Dharma Suci- Jakarta). Jurnal Pengabdian Dan Kewirausahaan, 3(2), 83-90. Retrieved from https://journal.ubm.ac.id/index.php/pengabdian-dankewirausahaan/article/view/1863/1560

Harto, D., Pratiwi, S. R., Utomo, M. N., \& Rahmawati, M. (2019). Penerapan Internet Marketing Dalam Meningkatkan Pendapatan Pada UMKM. JPPM (Jurnal Pengabdian Dan Pemberdayaan Masyarakat), 3(1), 39. https://doi.org/10.30595/jppm.v3i1.3033

Kosasi, S. (2014). Pembuatan Sistem Informasi Penjualan Berbasis Web Untuk Memperluas Pangsa Pasar. In SNATIF (pp. 225-232). Kudus: Universitas Muria Kudus.

Kusno, T. S., \& Andri, K. B. (2011). Laporan Rancang Bangun Pengembangan Agribisnis Tanaman Bunga Krisan di Propinsi Jawa Timur. Surabaya.

Tinaprilla, N., \& Pratiwi, C. P. (2017). Potensi Agribisnis Florikultura di Indonesia. In B. Krisnamurthi \& Harianto (Eds.), Menuju AGRIBISNIS INDONESIA yang Berdaya Saing (2017th ed., pp. 89-105). Bogor: Raffi Offset. 